\title{
Essential Roles of c-JUN and c-JUN N-Terminal Kinase (JNK) in Neuregulin-Increased Expression of the Acetylcholine Receptor $\epsilon$-Subunit
}

\author{
Jutong Si, Qi Wang, and Lin Mei \\ Department of Pharmacology, University of Virginia School of Medicine, Charlottesville, Virginia 22908
}

Neuregulin is a neural factor implicated in upregulation of acetylcholine receptor (AChR) synthesis at the neuromuscular junction. Previous studies have demonstrated that the extracellular signal-regulated kinase (ERK) subgroup of MAP kinases is required for neuregulin-induced $A C h R$ gene expression. We report here that the neuregulin-mediated increase in $A C h R$ $\epsilon$-subunit mRNA was a delayed response in C2C12 muscle cells. Neuregulin induced expression of immediate early genes c-jun and c-fos, which followed and depended on the ERK activation. Treatment of muscle cells with cycloheximide to inhibit c-JUN synthesis at the protein level and suppression of c-JUN function by a dominant-negative mutant blocked neuregulin-induced expression of the $\epsilon$-subunit gene, indicating an essential role of c-JUN in neuregulin signaling. Furthermore,

Synaptic transmission at the neuromuscular junction is guaranteed by a high density of acetylcholine receptor (AChR) at the postsynaptic membrane. AChR expression is regulated both spatially and temporally during development. AChR synthesis is confined to the adult neuromuscular junction (Froehner, 1993; Hall and Sanes, 1993; Sanes and Lichtman, 1999). Studies using transgenic mice have shown that the regulatory elements of AChR genes can direct the expression of reporter genes at the neuromuscular junction (Klarsfeld et al., 1987; Sanes et al., 1991; Simon et al., 1992; Gundersen et al., 1993), indicating that transcription of AChR genes is most active in nuclei beneath the postsynaptic membrane, contributing to the high density of $\mathrm{AChR}$ at the neuromuscular junction.

Synaptic expression of AChR genes is believed to be mediated by neuregulin, a family of factors that have been originally identified as acetylcholine receptor-inducing activity (ARIA) that stimulates muscle AChR synthesis (Fischbach and Cohen, 1973; Jessell et al., 1979; Falls et al., 1993), as ligands of the receptor tyrosine kinase erbB2 (neu differentiation factor and heregulin) (Wen et al., 1992), and as neuronal factors essential for the proliferation and survival of Schwann cells (glia growth factor) (Marchionni et al., 1993). They are products of the $n r g-1$ gene

Received March 22, 1999; revised June 9, 1999; accepted July 12, 1999.

This work was supported by the National Institutes of Health and the National Institute of Neurological Disorders and Stroke Grant NS34062 and grants from the Muscular Dystrophy Association and the March of Dimes Birth Defects Foundation to L.M. We are grateful to Drs. M. Sliwkowski, G. S. Feng, R. Huganir, T. Curran, A. Langley, R. Davis, and M. Birrer for valuable reagents and to Dr. Wen C. Xiong and Sandra Won for discussion and suggestions.

Correspondence should be addressed to Dr. Lin Mei, Department of Neurobiology, University of Alabama at Birmingham, CIRC 5th Floor, 1530 3rd Avenue South, Birmingham, AL 35294-0021.

Copyright (C) 1999 Society for Neuroscience 0270-6474/99/198498-11\$05.00/0 neuregulin activated c-JUN N-terminal kinase (JNK) in C2C12 muscle cells. Blockade of JNK activation by overexpressing dominant-negative MKK4 inhibited $\epsilon$-promoter activation. Moreover, overexpression of the JNK dominant-negative mutant inhibited neuregulin-mediated expression of the $\epsilon$ transgene and endogenous $\epsilon$-mRNA. Taken together, our results demonstrate important roles of c-JUN and JNK in neuregulin-mediated expression of the AChR $\epsilon$-subunit gene and suggest that neuregulin activates multiple signaling cascades that converge to regulate AChR $\epsilon$-subunit gene expression.

Key words: neuregulin; AChR; c-JUN; JNK; neuromuscular junction; synapse; immediate early gene generated by alternative splicing. Four lines of evidence indicate that neuregulin is a trophic factor released from motoneurons to regulate AChR synthesis at the neuromuscular junction. First, neuregulin heterozygous mutant mice that produce a low amount of neuregulin have a decreased postsynaptic AChR density and are myasthenic (Sandrock et al., 1997). Second, neuregulin mRNA is expressed in motoneurons before the onset of the neuromuscular junction and persists through adulthood (Fischbach and Rosen, 1997; Sandrock et al., 1997). Third, neuregulin accumulates in synaptic basal lamina in adult skeletal muscle (Chu et al., 1995; Goodearl et al., 1995; Jo et al., 1995; Sandrock et al., 1995), and ErbB proteins, neuregulin's receptors, are localized at the neuromuscular junction (Altiok et al., 1995; Z hu et al., 1995). Last, in cultured muscle cells, neuregulin promotes AChR synthesis both at the protein level (Jessell et al., 1979; Usdin and Fischbach, 1986; Sandrock et al., 1997) and at the level of mRNA (Martinou et al., 1991; Tang et al., 1994; Chu et al., 1995).

Until recently, little was known about the signaling mechanism of neuregulin in the regulation of $\mathrm{AChR}$ gene expression. The ErbB2 and ErbB3 proteins become tyrosine phosphorylated in response to neuregulin (Corfas et al., 1993; Altiok et al., 1995; Jo et al., 1995; Si et al., 1996). Concomitantly, extracellular signalregulated kinase (ERK) activity (Si et al., 1996; Tansey et al., 1996; Altiok et al., 1997) and phosphatidylinositol 3 (PI 3)-kinase activity (Tansey et al., 1996) are increased. Activation of ERK kinase is required for neuregulin regulation of AChR gene expression in cultured muscle cells (Si et al., 1996; Tansey et al., 1996; Altiok et al., 1997) and for synapse-specific expression of the $\epsilon$-transgene in vivo ( $\mathrm{Si}$ and Mei, 1999). Here we report that the neuregulin-mediated increase in AChR $\epsilon$-subunit mRNA was a delayed response. Neuregulin induced expression of immediate 
early genes $c$-jun and $c$-fos and activated c-JUN N-terminal kinase $(\mathrm{JNK})$, both of which were required for the $\epsilon$-promoter transcription.

\section{MATERIALS AND METHODS}

Materials. Recombinant neuregulin $\left(\mathrm{rHRG}_{\beta 1} 177-244\right.$, a peptide of $\mathrm{HRG}_{\beta 1}$ residues 177-244) was generously provided by Dr. M. Sliwkowski (Holmes et al., 1992). Anti-ERK kinase antibody was a gift from Dr. G. S. Feng. The mouse AChR $\epsilon$-subunit cDNA was provided by Dr. R. Huganir. The $c$-fos and $c$-jun cDNAs were provided by Drs. T. Curran and A. Langley (Curran et al., 1987). Dr. R. Davis provided JNK1, MKK4, and p38 constructs (Whitmarsh et al., 1997), and Dr. M. Birrer provided the c-JUN mammalian expression constructs (Brown et al., 1994). PD98059, AG1478, and SB202190 were purchased from Calbiochem (La Jolla, CA). Rapamycin was from Research Biochemicals (Natick, MA). Cell culture media were purchased from Life Technologies (Gaithersburg, MD). Anti-FLAG antibody and all other chemicals were from Sigma (St. Louis, MO).

Cell culture and transfection procedures. Mouse muscle C2C12 cells were maintained as undifferentiated myoblasts in a nutrient-rich growth medium containing DMEM supplemented with $20 \%$ fetal bovine serum, $0.5 \%$ chicken embryo extract, $2 \mathrm{~mm} \mathrm{~L}$-glutamine, $100 \mathrm{U} / \mathrm{ml}$ penicillin, and $100 \mu \mathrm{g} / \mathrm{ml}$ streptomycin at $37^{\circ} \mathrm{C}$ in an atmosphere of $5 \% \mathrm{CO}_{2}$ and $95 \%$ humidity. To induce differentiation, we cultured myoblasts at $50-70 \%$ confluence in the differentiation medium (DM), DMEM supplemented with $4 \%$ horse serum, $2 \mathrm{mM}$ L-glutamine, $100 \mathrm{U} / \mathrm{ml}$ penicillin, and 100 $\mu \mathrm{g} / \mathrm{ml}$ streptomycin. For transient transfection, C2C12 myoblasts at $\sim 50 \%$ confluence in six-well plates were cotransfected with the $\epsilon 416$-Luc transgene $(1 \mu \mathrm{g}$ of DNA) and p-cytomegalovirus $\beta$ (pCMV $\beta ; 0.1 \mu \mathrm{g}$ of DNA) with or without $4 \mu \mathrm{g}$ of either wild-type or mutant c-JUN, MKK4, or JNK by the calcium phosphate technique (Sambrook et al., 1989). Twenty-four hours later cells were switched to DM. Myotubes then were treated with neuregulin for $24 \mathrm{hr}$. Stable $\mathrm{C} 2 \mathrm{C} 12$ cell lines carrying wild-type or mutant JNK were generated as described previously (Si et al., 1996).

Treatment of cells. Forty-eight hours after switching to DM, the $\mathrm{C} 2 \mathrm{C} 12$ myoblasts formed myotubes and were then treated with neuregulin. In experiments studying inhibitory effects, chemicals were added into the culture medium $30 \mathrm{~min}$ before neuregulin treatment and remained in the medium for the entire neuregulin stimulation period. The volume of solvent vehicles was kept $\leq 0.1 \%$ of the culture medium and did not significantly change the biological outcome. Culture medium was changed every $24 \mathrm{hr}$ to keep myotubes healthy.

Northern blot analysis. Total RNA was extracted from C2C12 muscle cells by the use of a single-step RNA-isolating method modified from that of Chomczynski and Sacchi (1987). Briefly, cells of a $10 \mathrm{~cm}$ dish were lysed in $10 \mathrm{ml}$ of the RNA-extracting buffer containing $2 \mathrm{M}$ guanidinium thiocyanate, $12.5 \mathrm{~mm}$ sodium citrate, $\mathrm{pH} 7.0,50 \mathrm{~mm} \beta$-mercaptoethanol, $0.25 \% \mathrm{~N}$-lauroylsarcosine, $0.1 \mathrm{M}$ sodium acetate, and $50 \%$ phenol. After the addition of $2 \mathrm{ml}$ of chloroform, the lysate was mixed vigorously and subjected to a centrifugation at $8000 \times g$ at $4^{\circ} \mathrm{C}$ for $20 \mathrm{~min}$. The aqueous phase was mixed with an equal volume of isopropanol, and total RNA was isolated in the pellet of another centrifugation at $8000 \times g$ at $4^{\circ} \mathrm{C}$ for $20 \mathrm{~min}$. Unless otherwise indicated, $20 \mu \mathrm{g}$ of total RNA was resolved on a $1 \%$ agarose gel by electrophoresis in 3 - $(N$-morpholino)propanesulfonic acid-formaldehyde buffer as described by Lehrach et al. (1977). RNA was transferred to a nylon membrane in $20 \times$ SSC by capillary transfer and cross-linked to the membrane by the use of a UV cross-linker. The membrane filters were probed with a cDNA fragment of the $\epsilon$-subunit or glyceraldehyde-3-phosphate dehydrogenase (GAPDH), both of which were labeled with $\left[\alpha-{ }^{32} \mathrm{P}\right] \mathrm{dCTP}$ by a random-prime method. RNA blots were hybridized in a buffer containing $6 \times$ SSC, $5 \times$ Denhardt's solution, $0.5 \%$ SDS, $50 \%$ formamide, and $200 \mu \mathrm{g} / \mathrm{ml}$ salmon sperm DNA at $42^{\circ} \mathrm{C}$ for $48 \mathrm{hr}$. The membrane filters were washed with $0.1 \times$ SSC and $0.5 \%$ SDS at $42^{\circ} \mathrm{C}$ four times, each for $15 \mathrm{~min}$, and exposed to Kodak X-Omat AR film (Eastman Kodak, Rochester, NY) at $-80^{\circ} \mathrm{C}$ with an intensifying screen.

Quantitative image analysis. The quantification was performed by image analysis of radioautographic films by scanning the film with the Personal Densitometer (Molecular Dynamics, Sunnyvale, CA), and the captured image was analyzed with the ImageQuant software (Molecular Dynamics).

ERK kinase assay. The ERK kinase assay was performed essentially as described previously (Si et al., 1996).
JNK and p38 MAP kinase assays. C2C12 myotubes were cultured in serum-free DMEM medium for $24 \mathrm{hr}$ before the stimulation with neuregulin. Myotubes were harvested in the lysis buffer containing $137 \mathrm{~mm}$ $\mathrm{NaCl}, 1 \%$ NP-40, 5 mm EDTA, 20 mm Tris-HCl, pH 7.5, $1 \mu \mathrm{m}$ pepstatin, $1 \mu \mathrm{g} / \mathrm{ml}$ leupeptin, $0.2 \mathrm{~mm}$ PMSF, $2 \mu \mathrm{g} / \mathrm{ml}$ aprotinin, and $2 \mathrm{~mm}$ sodium vanadate. JNK was purified as described previously (Whitmarsh et al., 1997). Briefly, an aliquot of lysate (400 $\mu \mathrm{g}$ of protein) was incubated with $10 \mu \mathrm{g}$ of glutathione $S$-transferase (GST)-c-JUN (human c-JUN amino acids 1-79) fusion protein immobilized on agarose beads in a final volume of $0.4 \mathrm{ml}$ at $4^{\circ} \mathrm{C}$ for $2 \mathrm{hr}$. After being washed three times with the lysis buffer and twice with a buffer containing 20 mM HEPES, pH 7.5, and $20 \mathrm{mM} \mathrm{MgCl}_{2}$, the beads were then incubated in $30 \mu \mathrm{l}$ of the kinase assay buffer containing $20 \mathrm{~mm}$ HEPES, $\mathrm{pH} 7.5,20 \mathrm{~mm} \mathrm{MgCl}_{2}, 20 \mathrm{~mm}$ $\beta$-glycerophosphate, $0.1 \mathrm{~mm}$ sodium vanadate, $20 \mu \mathrm{M}$ ATP, $2 \mathrm{~mm}$ DTT,
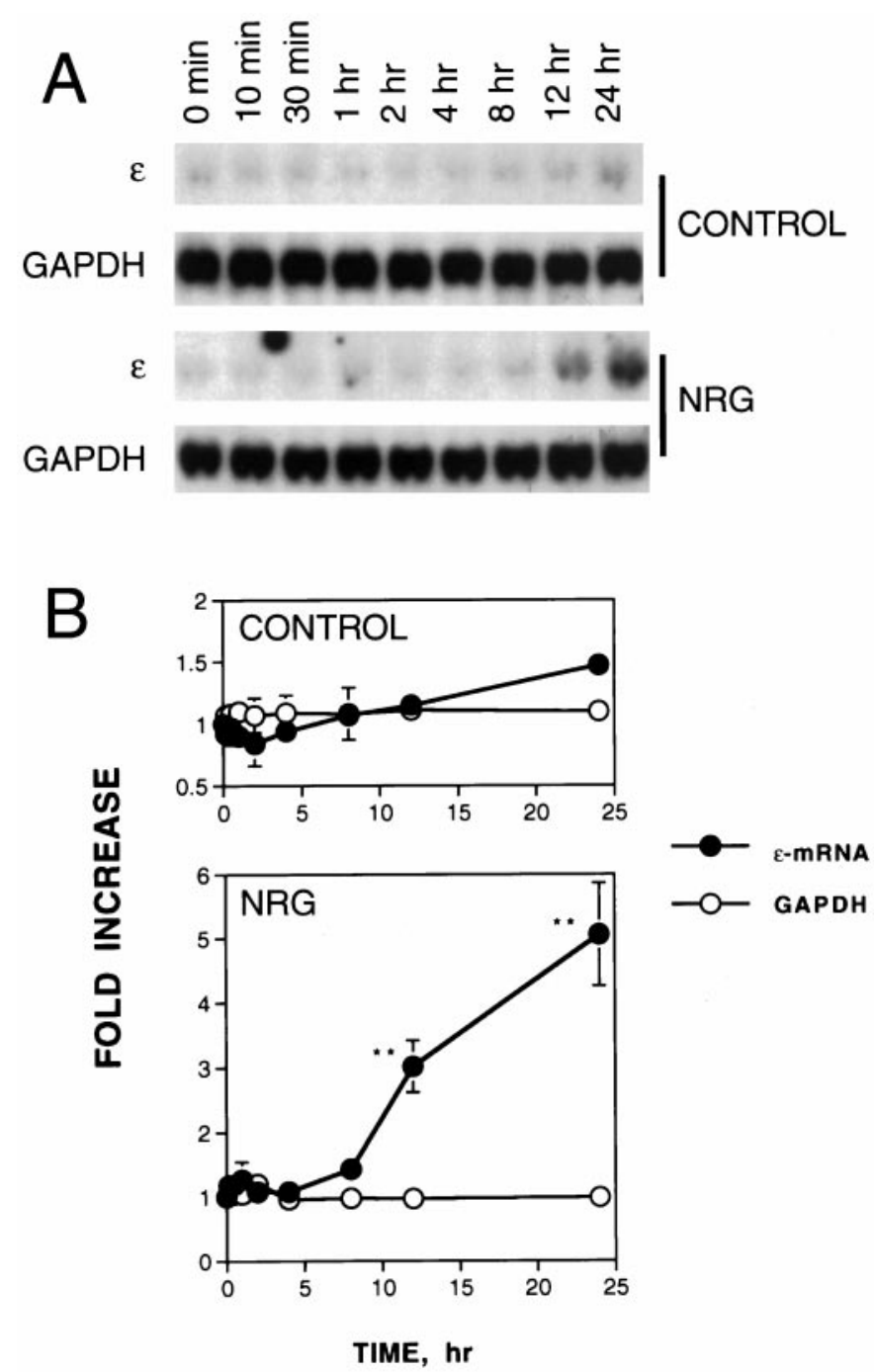

Figure 1. Delayed increase in the AChR $\epsilon$-subunit mRNA by neuregulin in $\mathrm{C} 2 \mathrm{C} 12$ myotubes. Stimulation of $\mathrm{C} 2 \mathrm{C} 12$ myotubes was started by the addition of neuregulin $(N R G)$ to a final concentration of $1 \mathrm{~nm}$ or an equal volume of vehicle (as a control). Cells were harvested for RNA isolation at the indicated times. Twenty micrograms of total RNA were resolved on a $1 \%$ agarose gel, transferred to nitrocellulose, and hybridized with $\left[{ }^{32} \mathrm{P}\right]$-labeled DNA probes specific for the $\epsilon$-subunit. The loading was uniform as evidenced by an equal amount of GAPDH mRNA. A, Representative Northern blot radiograms. $B$, Histograms showing mean $\pm \mathrm{SD}$ of two different samples. The mRNA levels at 0 min were considered to be $100 \%$. * $p<0.01$. 


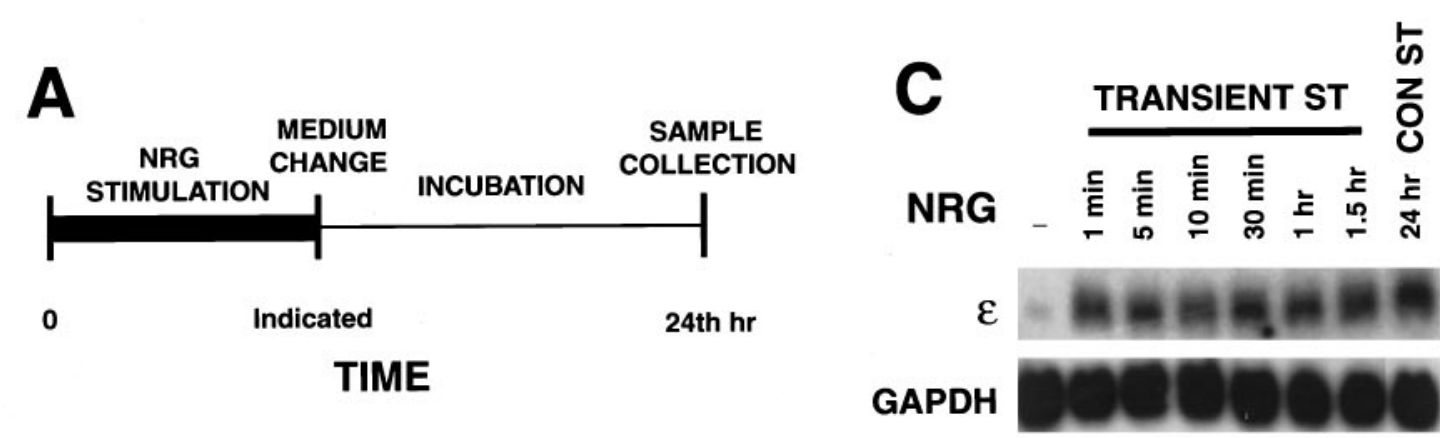

B
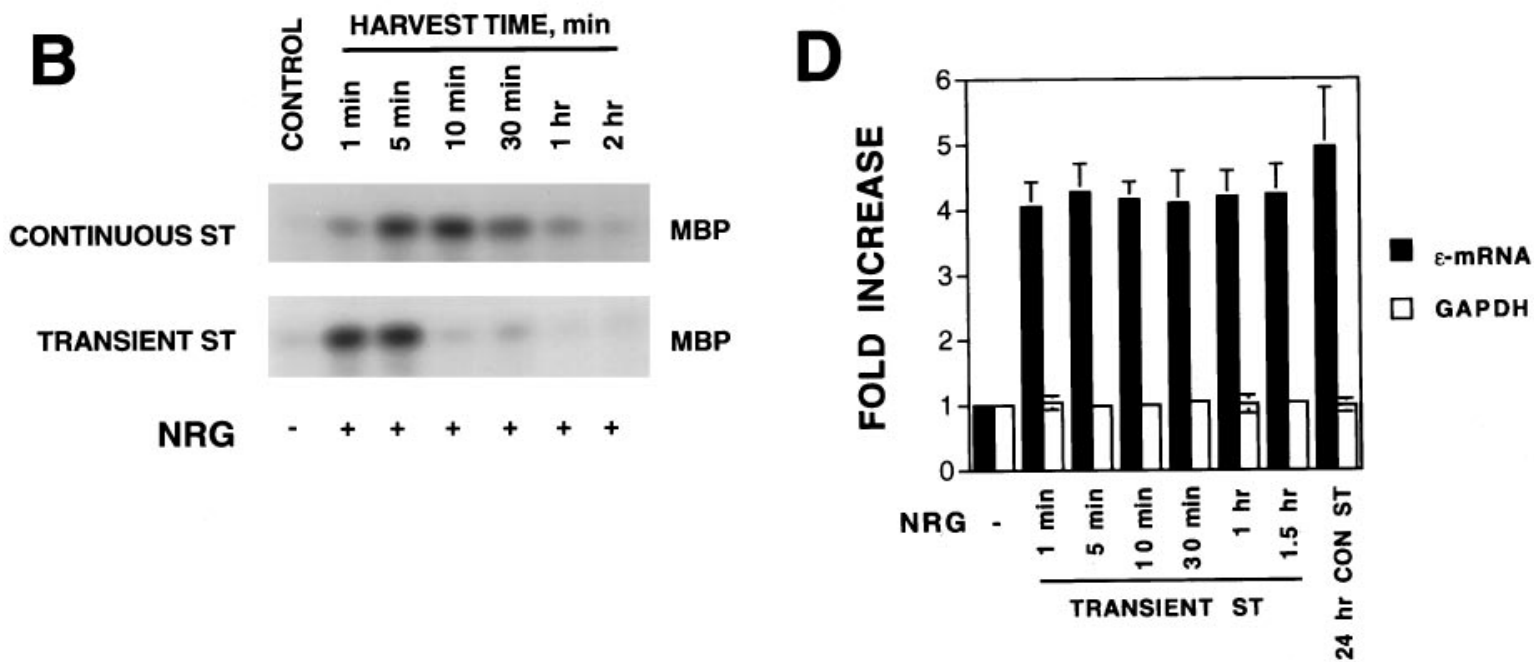

Figure 2. Increase in the AChR $\epsilon$-mRNA by transient stimulation with neuregulin. $A$, Stimulation protocol. Stimulation of myotubes with $N R G$ Defined in Figure 1. began at time 0; after an incubation for the indicated time, the cells were washed and incubated in neuregulin-free medium. At 24 hr, cells were lysed to isolate total RNA, which was then blotted for AChR mRNA expression. B, Activation of ERK kinase by neuregulin. Top, C2C12 myotubes stimulated continuously without (control) or with $1 \mathrm{~nm}$ neuregulin for the indicated times. Bottom, C2C12 myotubes stimulated with 1 nM neuregulin for $1 \mathrm{~min}$ and then incubated in neuregulin-free medium for the indicated times. Control C2C12 myotubes were treated with an equal volume of DMEM (vehicle) without neuregulin for 5 min. ERK kinase was immunoprecipitated and assayed using MBP as a substrate in vitro with $\left[\gamma^{32} \mathrm{P}\right] \mathrm{ATP}$. The phosphorylated MBP was resolved on a $15 \%$ SDS gel and exposed to x-ray film. $C$, Northern blot radiograms. C2C12 myotubes were stimulated as described in $A$. Control C2C12 myotubes were treated with the same volume of DMEM (without neuregulin) for 24 hr. Twenty micrograms of total RNA were probed with $\left[{ }^{32} \mathrm{P}\right]$-labeled $\epsilon$-subunit probe. $D$, Histograms showing mean $\pm \mathrm{SD}$ of three different samples. The mRNA levels in the absence of neuregulin were considered to be $100 \%$. CON ST, Continuous stimulation; ST, stimulation.

and $5 \mu \mathrm{Ci}$ of $\left[\gamma^{-}{ }^{32} \mathrm{P}\right] \mathrm{ATP}$ at $30^{\circ} \mathrm{C}$ for $15 \mathrm{~min}$. The p38 MAP kinase was purified from the cell lysate using $50 \mu \mathrm{l}$ of protein $\mathrm{G}$-agarose beads $(1: 1$ slurry) preloaded with goat anti-p38 MAP kinase antibodies (Santa Cruz Biotechnology, Santa Cruz, CA) and assayed using as a substrate $2 \mu \mathrm{g}$ of the GST-ATF2 fusion protein in the same phosphorylation buffer. The kinase reaction was stopped by the addition of $10 \mu \mathrm{l}$ of $4 \times$ sampleloading buffer and subjected to electrophoresis on a $10 \%$ SDSpolyacrylamide gel that was then exposed to an x-ray film.

Luciferase and $\beta$-galactosidase assays. The luciferase assay was performed using a kit from Promega (Madison, WI) and following the manufacturer's instructions. Briefly, $100 \mu \mathrm{l}$ of cell lysate was mixed in an equal volume of luciferase substrate solution containing $20 \mathrm{~mm}$ Tricine, $1.07 \mathrm{~mm}\left(\mathrm{MgCO}_{3}\right)_{4} \mathrm{Mg}(\mathrm{OH})_{2} \cdot 5 \mathrm{H}_{2} \mathrm{O}, 2.67 \mathrm{~mm} \mathrm{MgSO}_{4}, 0.1 \mathrm{~mm}$ EDTA, $33.3 \mathrm{~mm}$ DTT, $270 \mu \mathrm{M}$ coenzyme A, $470 \mu \mathrm{M}$ luciferin, and $530 \mu \mathrm{M}$ ATP and was placed in a micro $\beta$ luminometer (Wallac, Turku, Finland) to measure light production for $10 \mathrm{sec}$. $\beta$-Galactosidase activity was determined as described previously (Si et al., 1996). Luciferase activity of transgenes was normalized to $\beta$-galactosidase activity to correct for variation in transfection.

Protein concentration determination. Protein concentration was measured by the Bradford method using a Coomassie Protein Assay Reagent (Pierce, Rockford, IL) with BSA as a standard (Bradford, 1976).

Statistical analysis. Values were shown as mean \pm SD. Statistical differences were analyzed using the one-tailed Student's $t$ test. A value of $p<0.05$ is considered statistically significant.

\section{RESULTS}

\section{Delayed increase in AChR $\epsilon$-subunit mRNA in neuregulin-stimulated C2C12 myotubes}

The basal level of the $\epsilon$-mRNA in $\mathrm{C} 2 \mathrm{C} 12$ myoblasts was barely detectable and remained low until 3-4 d after the cells were switched to DM (data not shown). Neuregulin stimulation did not increase the $\epsilon$-subunit expression in $\mathrm{C} 2 \mathrm{C} 12$ myoblasts ( $\mathrm{Si}$ et al., 1996). We studied the time course of neuregulin in the increase of AChR gene expression in $\mathrm{C} 2 \mathrm{C} 12$ myotubes. Forty-eight hours after the medium switch when myotube formation was complete, cells were stimulated with $1 \mathrm{~nm}$ neuregulin for various times. In the presence of neuregulin, AChR $\epsilon$-mRNA remained unchanged until 8-12 hr later when an increase was detectable. The neuregulin-induced increase in the $\epsilon$-mRNA became robust $24 \mathrm{hr}$ after stimulation (Fig. 1). The increase in the $\epsilon$-mRNA by neuregulin was specific because neuregulin had no effect on GAPDH mRNA (Fig. 1). The basal level of the $\epsilon$-mRNA (in the absence of neuregulin) did not change significantly during the time of the experiment (Fig. $1 A$, top). Figure $1 B$ shows the means of two separate experiments. The expression of other AChR subunit 
A Actinomycin D Pretreatment

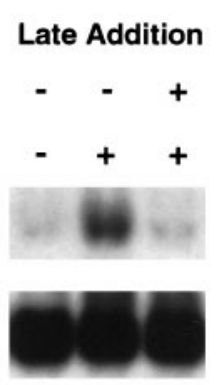

B GAPDH
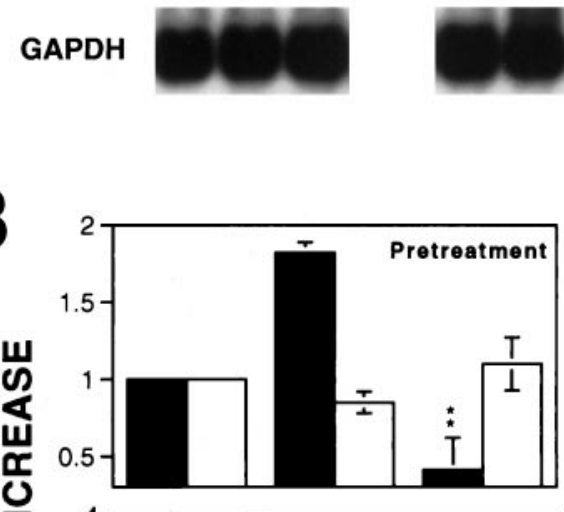
$\underline{U}$

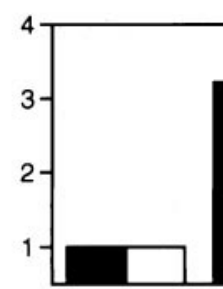

Actinomycin D NRG

Figure 3. Inhibition of the neuregulin-mediated increase in AChR $\epsilon$-mRNA by actinomycin D. C2C12 myotubes were pretreated with 5 $\mu \mathrm{g} / \mathrm{ml}$ actinomycin $\mathrm{D}$ for $30 \mathrm{~min}$ before $1 \mathrm{nM}$ neuregulin stimulation for 12 hr. In the late-addition experiments, $\mathrm{C} 2 \mathrm{C} 12$ cells were stimulated with 1 $\mathrm{nM}$ neuregulin for $12 \mathrm{hr}$ to increase the $\epsilon$-mRNA. Actinomycin D (5 $\mu \mathrm{g} / \mathrm{ml}$ ) was then added in the medium. After incubation for another $4 \mathrm{hr}$, $\mathrm{C} 2 \mathrm{C} 12$ myotubes were collected for Northern blotting using $20 \mu \mathrm{g}$ of total RNA. $A$, Representative Northern blot radiograms. $B$, Histograms showing mean $\pm \mathrm{SD}$ of two different samples. The mRNA levels in the absence of neuregulin were considered to be the control $(100 \%)$. ${ }^{* *} p<0.01$ in comparison with the neuregulin-mediated increase in the absence of actinomycin D.

genes in response to neuregulin followed a similar time course (data not shown).

\section{Increase in the $\epsilon$-mRNA by transient neuregulin stimulation}

Neuregulin-induced expression of $\mathrm{AChR}$ genes requires activation of the ERK subgroup of MAP kinases in cultured muscle cells (Si et al., 1996; Tansey et al., 1996; Altiok et al., 1997). The increase in ERK kinase activity by neuregulin is transient with a peak at $\sim 5-8$ min after neuregulin stimulation (Fig. $2 B$ ) (Si et al., 1996). The ERK kinase activity returns to the basal level within $60 \mathrm{~min}$ of neuregulin stimulation. Yet the increase in the $\epsilon$-mRNA was a delayed response (Fig. 1). These observations prompted us to determine the stimulation time sufficient for neuregulin to activate AChR gene expression. Previous experiments in the literature used a continuous stimulation protocol, in which neuregulin was present in the culture medium until cells were harvested.

To study this, we have designed the protocol depicted in Figure
$2 A$. Neuregulin stimulation of myotubes began at time 0 ; after an incubation of the indicated time, cells were washed and incubated in neuregulin-free DM. At $24 \mathrm{hr}$, total RNA was isolated and assayed for AChR expression. As shown in Figure $2 B$, exposure of $\mathrm{C} 2 \mathrm{C} 12$ myotubes to neuregulin for as short as $1 \mathrm{~min}$ was sufficient to activate ERK MAP kinases and subsequently increase the AChR $\epsilon$-mRNA (Fig. $2 C$ ). The $\epsilon$-mRNA level increased by transient neuregulin stimulation was comparable with that induced by the continuous stimulation (Fig. 2D). In vivo neuregulin binds to the extracellular matrix via the Ig-like domain in the $\mathrm{N}$ terminus (Loeb and Fischbach, 1995) and thus becomes concentrated at the neuromuscular junction. The recombinant neuregulin used in this study contained only the epidermal growth factor domain and should not bind to the extracellular matrix. Thus, ERK activation was more transient by neuregulin stimulation in the transient stimulation protocol. These results suggest that the initiation of the signal pathways required for neuregulin-increased AChR gene expression may be completed within $1 \mathrm{~min}$. After being activated, AChR gene transcription machinery remained active even in the absence of neuregulin.

To determine whether the $\epsilon$-mRNA elevation reflects an increase in transcription of the $\epsilon$-subunit gene, we studied the effect of actinomycin D, an inhibitor of RNA polymerases, on neuregulin's action. Treatment of $\mathrm{C} 2 \mathrm{C} 12$ myotubes with actinomycin D decreased the basal level of the $\epsilon$-mRNA (data not shown). Pretreatment with actinomycin $\mathrm{D}$ prevented the neuregulinmediated increase in the $\epsilon$-mRNA in $\mathrm{C} 2 \mathrm{C} 12$ myotubes, suggesting an important role of active transcription in increasing the AChR mRNA (Fig. $3 A$ ). Furthermore, the addition of actinomycin D after neuregulin stimulation decreased the $\epsilon$-mRNA, suggesting that the sustained elevation also requires active transcription (Fig. 3B). These results demonstrated that both the initial increase and the maintenance of the $\epsilon$-mRNA depended on active transcription in $\mathrm{C} 2 \mathrm{C} 12$ myotubes.

\section{Induction of c-fos and c-jun immediate early genes by neuregulin}

To understand neuregulin's signaling mechanism further, we sought to identify genes whose expression was upregulated by neuregulin in $\mathrm{C} 2 \mathrm{C} 12$ myotubes. We and others have demonstrated previously that neuregulin activates ERK MAP kinase that is required for AChR subunit gene expression (Si et al., 1996; Tansey et al., 1996; Altiok et al., 1997). Moreover, evidence is compelling that the Ras-ERK pathway regulates transcription of immediate early genes such as $c$-jun and $c$-fos in a variety of cells (Segal and Greenberg, 1996). We determine whether neuregulin regulates $c$-fos and $c$-jun expression in $\mathrm{C} 2 \mathrm{C} 12$ cells. Neuregulin had no apparent effect on the level of $c$-jun and $c$-fos mRNAs in C2C12 myoblasts (Fig. 4A). However, both $c$-jun and $c$-fos mRNAs were increased by neuregulin within $5 \mathrm{~min}$ in $\mathrm{C} 2 \mathrm{C} 12$ myotubes (Fig. 4B). These results indicate that, as observed with AChR gene expression in $\mathrm{C} 2 \mathrm{C} 12$ cells ( $\mathrm{Si}$ et al., 1996), the neuregulin induction of $c$-jun and $c$-fos genes depended on cell differentiation. The $c-j u n$ expression peaked at $\sim 10 \mathrm{~min}$, whereas the $c$-fos expression maximized at $\sim 30 \mathrm{~min}$ after the stimulation. Both mRNAs returned to the basal level (i.e., before stimulation) within $90 \mathrm{~min}$. The neuregulin-induced expression of $c$-jun and c-fos had a concentration-response relationship (Fig. 4C) similar to that of neuregulin-induced AChR gene expression (Si et al., 1996).

To determine the signaling mechanism of neuregulin in the regulation of the expression of $c$-jun and $c$-fos genes, we studied 
Figure 4. ERK kinase-dependent increase in $c$-jun and $c$-fos mRNAs in $\mathrm{C} 2 \mathrm{C} 12$ myotubes by neuregulin. $A$, Effect of neuregulin on $c$-jun and $c$-fos mRNA levels in myoblasts. $B$, Time course of $N R G$-induced expression of $c$-jun and $c$-fos in myotubes. $C$, Concentration-response relationship of neuregulininduced expression of $c$-jun and $c$-fos in myotubes. The fold increase by neuregulin in $\mathrm{C} 2 \mathrm{C} 12$ cells was $5.2 \pm 0.28$ for $c$-fos and $2.4 \pm 0.11$ for $c$-jun mRNAs. $D$, Dependence of neuregulin-induced expression of $c$-jun and $c$-fos on ERK kinase activation. C2C12 myoblasts were treated with $10 \mathrm{~nm}$ neuregulin, $10 \%$ serum, or vehicle (control) for $30 \mathrm{~min}(A)$. Myotubes were treated with $1 \mathrm{~nm}$ neuregulin for the indicated times $(B)$ or with various concentrations of neuregulin for $30 \mathrm{~min}(C)$. C2C12 myotubes were pretreated with 40 or $80 \mu \mathrm{M}$ PD98059 (lower concentration of each treatment in the left-hand lane), $200 \mathrm{nM}$ or $1 \mu \mathrm{M}$ rapamycin, $200 \mathrm{nM}$ or $1 \mu \mathrm{M}$ wortmannin, or $10 \mathrm{nM}$ or $1 \mu \mathrm{M}$ tyrphostin AG1478 for $30 \mathrm{~min}$ before stimulation with $1 \mathrm{~nm}$ neuregulin for $30 \mathrm{~min}(D)$. Twenty micrograms of total RNA isolated from neuregulintreated myotubes were resolved on a $1 \%$ agarose gel, blotted to nitrocellulose, and probed with $\left[{ }^{32} \mathrm{P}\right]-$ labeled $c$-jun or $c$-fos cDNA fragments.

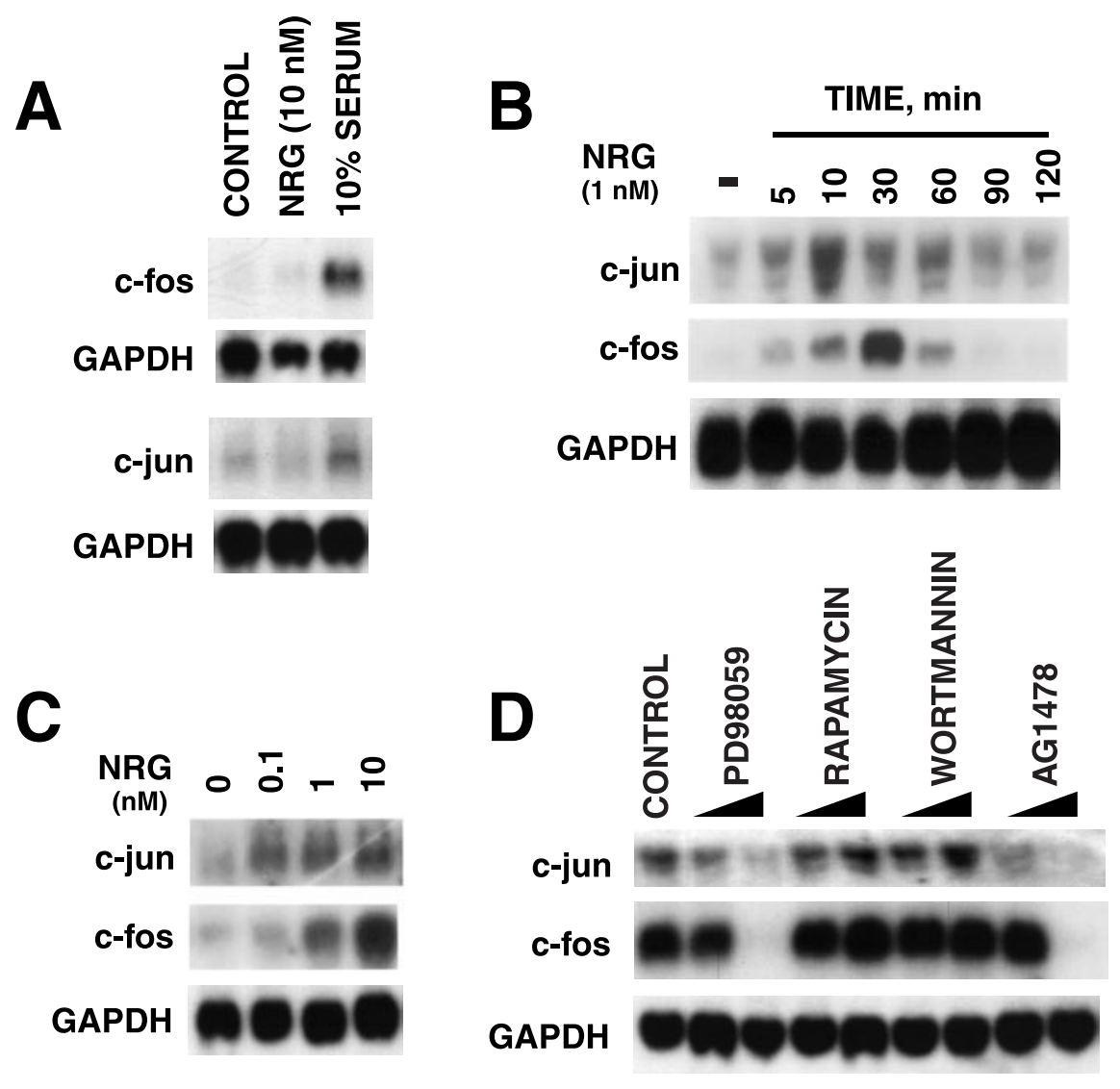

the effect of several chemicals known to affect the activity of ErbB protein tyrosine kinases, ERK, and PI 3-kinase in C2C12 myotubes (J. Si and L. Mei, unpublished observation). Pretreatment with tyrphostin AG1478, a potent and selective inhibitor of ErbB protein kinases (Levitzki and Gazit, 1995), and PD98059, an inhibitor of MEK (Dudley et al., 1995), had no effect on the basal levels of $c$-jun and $c$-fos mRNAs (data not shown) yet blocked the neuregulin-induced increase in $c$-jun and $c$-fos mRNAs in a concentration-dependent manner (Fig. 4D). The inhibitory effect of tyrphostin AG1478 and PD98059 was specific because they had no effect on the GAPDH mRNA. In contrast, the PI 3-kinase inhibitor wortmannin (Carraway et al., 1995) and the S6 kinase inhibitor rapamycin (Chung et al., 1992) did not appear to affect the basal or neuregulin-induced $c$-jun and $c$-fos mRNA. These results demonstrated that neuregulin-induced expression of $c$-jun and $c$-fos genes in $\mathrm{C} 2 \mathrm{C} 12$ myotubes, like neuregulin-mediated AChR subunit gene expression (Si et al., 1996; Altiok et al., 1997), requires the activation of the ERK subgroup of MAP kinases but not PI 3-kinase.

\section{Inhibition of neuregulin-induced $\epsilon$-mRNA expression by cycloheximide}

The similar concentration-response curves of neuregulin in the induction of immediate early genes and in the upregulation of AChR genes (Fig. 4C) (Si et al., 1996) and their dependence on ERK activation (Fig. 4D) (Si et al., 1996; Tansey et al., 1996; Altiok et al., 1997) indicated a strong correlation between these two events. Immediate early gene expression peaked at 10-30 min, which was after ERK activation (5-10 $\mathrm{min}$ ) but before the increase in AChR mRNAs (8-12 hr). These results raised the possibility that $\mathrm{AChR}$ transcriptional activation may require the previous induction and expression of immediate early genes. To address this possibility, we determined whether neuregulin was capable of increasing AChR mRNA expression in the presence of cycloheximide, a protein synthesis inhibitor that is known to block expression of the proteins encoded by immediate early genes (Greenberg et al., 1986). Treatment of C2C12 myotubes with $10 \mu \mathrm{g} / \mathrm{ml}$ cycloheximide had no effect on basal expression of the $\epsilon$-subunit (Fig. 5A). However, pretreatment with cycloheximide completely inhibited the neuregulin-mediated increase in the $\epsilon$-mRNA (Fig. 5A,B), suggesting that the $\epsilon$-subunit gene transcription required de novo protein synthesis. The inhibitory effect of cycloheximide did not appear to result from its potential toxicity because GAPDH mRNA did not change in these cells. Because cycloheximide alone did not affect the basal level of the $\epsilon$-mRNA, it is unlikely that the decrease in neuregulin-induced $\epsilon$-mRNA by cycloheximide is attributable to inhibiting synthesis of an mRNA-stabilizing factor. In the latter case, treatment with cycloheximide should lead to an increase in $\epsilon$-mRNA in the absence of neuregulin. In contrast, cycloheximide blocked the neuregulin-mediated increase in the $\epsilon$-mRNA. These results suggest that products of immediate early genes may be involved in regulation of $\epsilon$-mRNA expression. It is worth noting that neuregulin was still able to induce immediate early gene $c$-fos mRNA expression in the presence of cycloheximide (Fig. $5 C$ ) that does not require de novo protein synthesis. Furthermore, the $c$-fos mRNA was superinduced by neuregulin in the presence of cycloheximide (Fig. 5C). Cycloheximide has been shown to increase the stability of immediate early gene mRNAs and thus to lead to a superinduction (Greenberg and Ziff, 1984; Greenberg et al., 1986). 

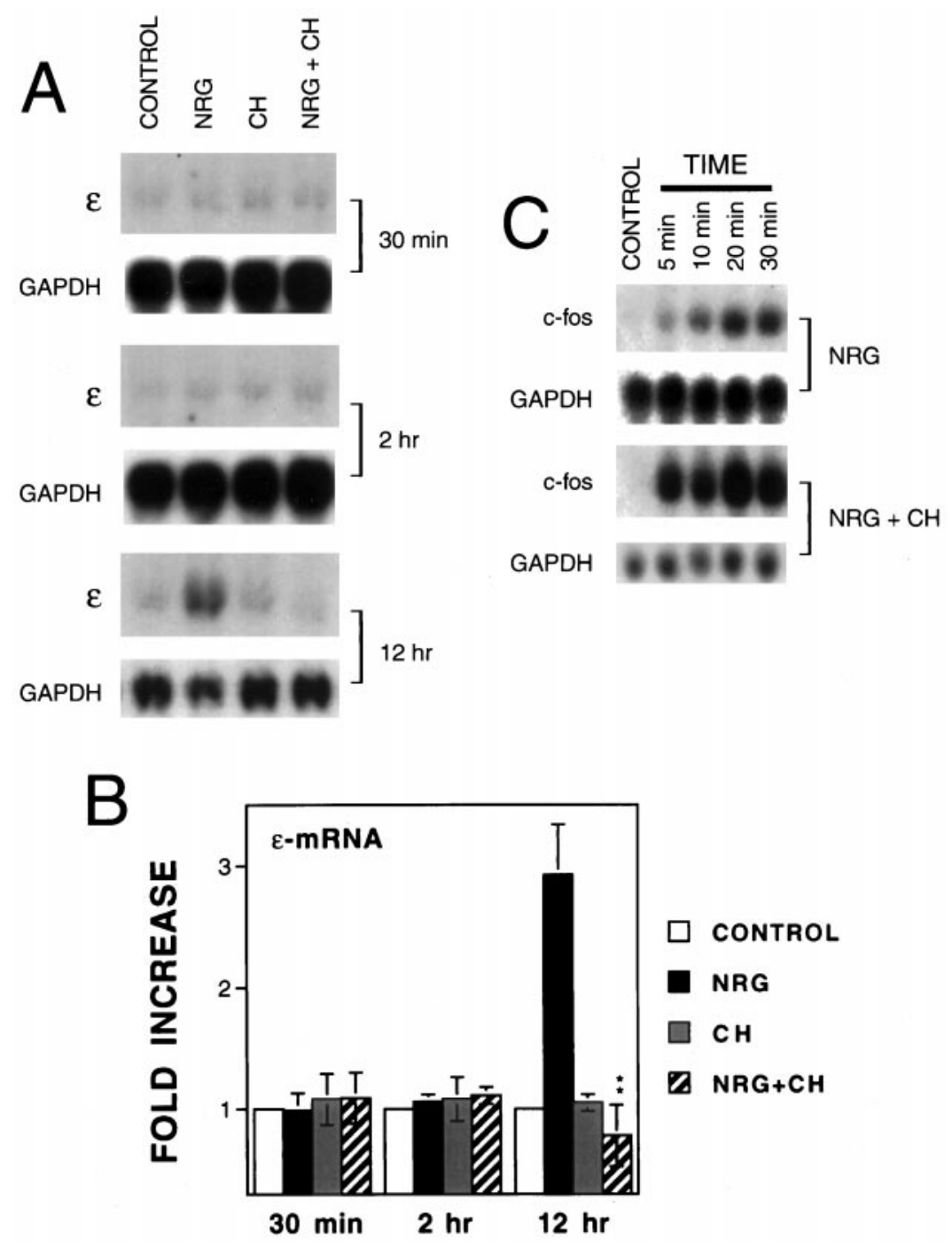

Figure 5. Inhibition by cycloheximide of the neuregulinmediated increase in the $\epsilon$-mRNA. C2C12 myotubes were treated with or without $10 \mu \mathrm{g} / \mathrm{ml}$ cycloheximide $(\mathrm{CH})$ for $30 \mathrm{~min}$ before neuregulin stimulation for the indicated times. Total RNA was isolated for Northern blot analysis using the respective probe for the $\epsilon$-subunit or $c$-fos. The loading was uniform as evidenced by an equal amount of GAPDH mRNA. A, Representative Northern blot radiograms of the $\epsilon$-mRNA. $B$, Histograms showing mean \pm SD of three different samples. The mRNA levels in the absence of neuregulin were considered to be $100 \%$ for the indicated time treatment. ${ }^{* *} p<0.01$ in comparison with the neuregulin-mediated increase in the absence of cycloheximide. $C$, Representative Northern blot radiograms of the $c$-fos mRNA.

\section{Requirement of C-JUN in neuregulin-induced $\epsilon$-subunit gene expression}

Because c-FOS has to form a heterodimer with c-JUN to be functional whereas c-JUN can form functional homodimers (Angel and Karin, 1991), inhibition of c-JUN function should affect the neuregulin induction of the $\epsilon$-subunit gene if it depends on the function of immediate early gene products. Therefore, we next investigated the role of c-JUN in the regulation of AChR gene expression using a dominant-negative $(\mathrm{D} / \mathrm{N})$ approach. The c-JUN dominant-negative mutant TAM-67 lacks amino acids 3-122 and has been shown previously to function as a potent inhibitor of c-JUN-mediated transcriptional activation (Brown et al., 1994, 1996). Because of a low transient transfection efficiency in $\mathrm{C} 2 \mathrm{C} 12$ cells, which made it difficult to study the effect of transfected c-JUN on expression of the endogenous AChR gene, we studied the effect of TAM-67 on the promoter-driven luciferase gene expression using the transgene $\epsilon 416$-Luc. $\epsilon 416$-Luc contains the 416 nucleotides of the $5^{\prime}$-flanking region of the $\epsilon$-subunit gene fused with the luciferase gene downstream of the transcription initiation site (Si et al., 1997). The 416 nucleotides contain cis-elements required for neuregulin induction in $\mathrm{C} 2 \mathrm{C} 12$ cells (Si et al., 1997) as well as synapse-specific expression (Duclert et al., 1993, 1996). C2C12 myoblasts were cotransfected with the transgene 6416 -Luc with the parental vector pCMV, wild type (WT) c-JUN, or TAM-67. The parental vector pCMV or c-JUN wild type had no effect on the neuregulin-induced $\epsilon$-transgene expression. In contrast, the $\mathrm{D} / \mathrm{N}$ mutant TAM-67 blocked the neuregulin-induced $\epsilon$-subunit gene expression in the $\mathrm{C} 2 \mathrm{C} 12$ cells (Fig. 6). These results argue that c-JUN is required for neuregulin-induced expression of the $\epsilon$-subunit gene. Coexpression of the c-JUN wild-type protein decreased the basal transgene expression, probably because of repressing transcriptional activation by myogenic transcription factors. There are two E box elements within the 416 nucleotide $5^{\prime}$-flanking region (Si et al., 1997). Mutation of the proximal E box decreased the basal but not the neuregulin-induced expression in Sol 8 muscle cells (Chu et al., 1995). c-JUN can interact physically with MyoD (Bengal et al., 1992) and thus inhibit trans-activation of the muscle creatine kinase enhancer by myogenic factors (Bengal et al., 1992; Li et al., 1992).

\section{Activation of JNK by neuregulin is required for its induction of the $\epsilon$-subunit gene expression}

The function of c-JUN is regulated by phosphorylation of the $\mathrm{N}$-terminal-transactivating domain by JNK, a subgroup of MAP kinases structurally related to ERK (Foletta, 1996). We deter- 


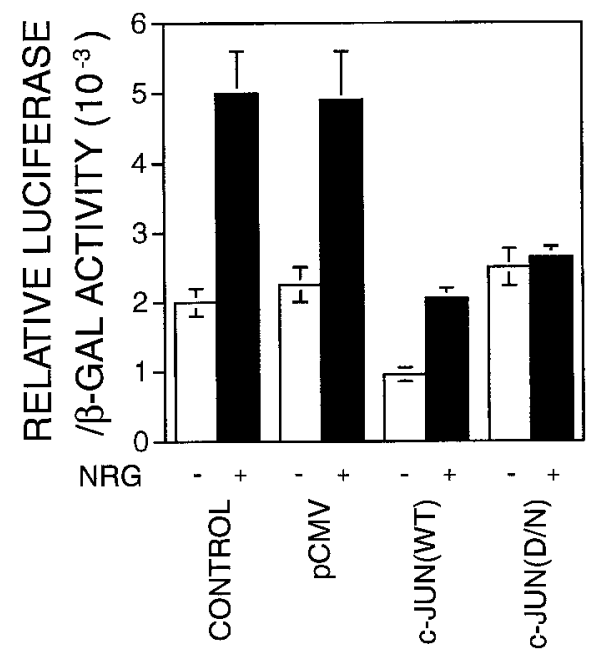

Figure 6. Dependence of the neuregulin-induced expression of the AChR $\epsilon$-transgene on c-JUN. C2C12 myoblasts were transiently cotransfected with $\epsilon 416-\mathrm{Luc}$ and $\mathrm{pCMV} \beta$ without (CONTROL) or with pCMV $(p C M V)$, pCMV-c-JUN [c-JUN $(W T)]$, or pCMV-TAM-67 [c-JUN $(D /$ $N)]$. Twenty-four hours after transfection, myoblasts were incubated with the DM to induce myotube formation. After another $48 \mathrm{hr}$, myotubes were stimulated with $1 \mathrm{~nm} N R G$ for $24 \mathrm{hr}$. Luciferase activity and $\beta$-galactosidase activity were assayed as described in Methods and Materials. The ratios of the relative luciferase or $\beta$-galactosidase activity in neuregulin-stimulated cells over that in control cells are shown. Histograms are mean $\pm \mathrm{SD}$ of four different samples.

mined whether neuregulin activates JNK in muscle cells. JNK was purified from control and neuregulin-stimulated $\mathrm{C} 2 \mathrm{C} 12$ cells and assayed using a GST-c-JUN fusion protein as a substrate. Stimulation of $\mathrm{C} 2 \mathrm{C} 12$ myotubes with neuregulin indeed increased the JNK activity in manners dependent on both concentration and time (Fig. 7). The JNK activation by neuregulin peaked at 10 min after stimulation and at $100 \mathrm{pm}$, which were $\sim 2.2$ - to 2.6-fold above the basal (Fig. 7).

To explore the role of JNK in the regulation of AChR gene expression, we studied effects of a JNK mutant on $\epsilon 416-\mathrm{Luc}$ expression. The JNK1(ALF) mutant is kinase deficient because its tripeptide dual phosphorylation motif Thr-Pro-Tyr has been mutated to Ala-Leu-Phe and thus cannot be activated by its upstream kinase (Gupta et al., 1995). The mutant and wild-type JNK were cotransfected in C2C12 cells with $\epsilon 416-$ Luc. As shown in Figure 8, the JNK kinase-deficient mutant blocked neuregulin-induced expression of the $\epsilon$-transgene, whereas the wild type had no apparent effect, suggesting an essential role of $\mathrm{JNK}$ or a related kinase in neuregulin regulation of the $\epsilon$-subunit gene. MKK4 is a kinase upstream of JNK that phosphorylates and thus activates JNK (Natali et al., 1992; Sanchez et al., 1994). To address further the importance of JNK or a related kinase in the regulation of $\mathrm{AChR}$ gene expression by neuregulin, a mutant MKK4 was introduced into $\mathrm{C} 2 \mathrm{C} 12$ cells, and its effect on neuregulin-induced expression of $\epsilon 416-\mathrm{Luc}$ was assessed. The MKK4(Ala) mutant, in which Ser257 and Thr261 are converted to Ala residues, cannot be phosphorylated or activated and thus functions as a dominant-negative mutant of MKK4 (Whitmarsh et al., 1995). Overexpression of MKK4 inhibits activation of JNK in mammalian cells (Whitmarsh et al., 1995). When it was cotransfected with $\epsilon 416-\mathrm{Luc}$, MKK4(Ala) effectively inhibited neuregulin-mediated induction of the $\epsilon$-promoter activity (Fig. 8).

In addition to JNK, p38 MAP kinase is another subgroup of
A

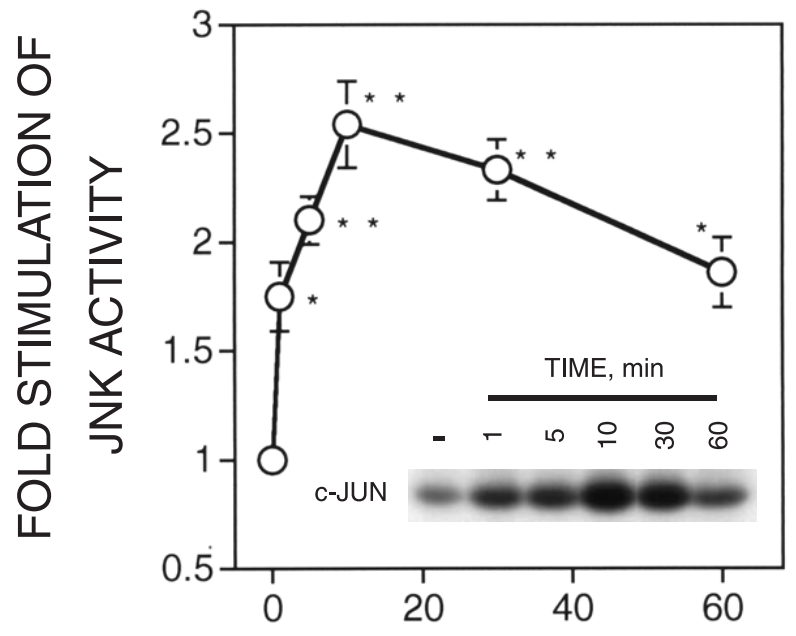

B

TIME, $\min$

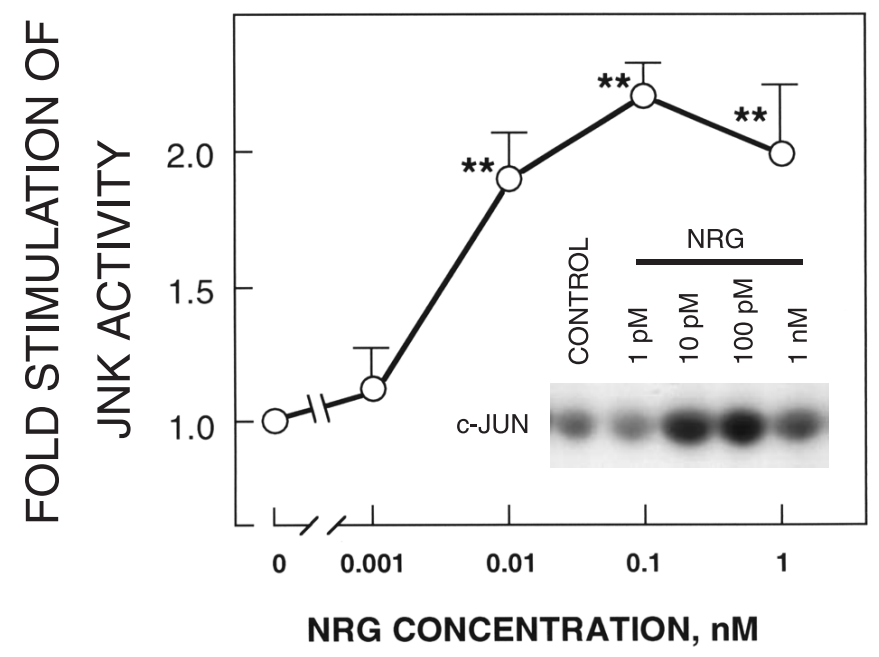

Figure 7. Activation of JNK in $\mathrm{C} 2 \mathrm{C} 12$ myotubes by neuregulin. $\mathrm{C} 2 \mathrm{C} 12$ myotubes were stimulated with $1 \mathrm{~nm}$ neuregulin for the indicated times $(A)$ or with various concentrations of neuregulin for $10 \mathrm{~min}(B)$ and then harvested in the lysis buffer. To purify JNK, we incubated an aliquot of lysate with agarose beads containing the GST-c-JUN fusion protein at $4^{\circ} \mathrm{C}$ for $2 \mathrm{hr}$. After washing, the beads were incubated in the kinase assay buffer containing $\left[\gamma_{-}^{32} \mathrm{P}\right] \mathrm{ATP}$ at $30^{\circ} \mathrm{C}$ for $15 \mathrm{~min}$. The kinase reaction was stopped by the addition of the sample-loading buffer and subjected to electrophoresis on a $10 \%$ SDS-polyacrylamide gel. Shown are means \pm SD of five different samples. The JNK activity levels in the absence of neuregulin were considered to be $100 \%$. The inset of each panel shows a representative radiogram. ${ }^{*} p<0.05 ; * * p<0.01$.

MAP kinases whose activity is activated by stress, proinflammatory cytokines, and lipopolysaccharide (Han et al., 1994; Raingeaud et al., 1995). We tested whether p38 MAP kinase is a regulator of neuregulin-mediated expression of AChR genes. P38 kinase was measured in an immune complex kinase assay using ATF2 as a substrate. Neuregulin did not appear to activate the p38 MAP kinase in $\mathrm{C} 2 \mathrm{C} 12$ myotubes (data not shown). Treatment of C2C12 myotubes with SB202190, an inhibitor of p38 (Lee et al., 1994), had no apparent effect on neuregulin-induced expression of the $\epsilon$-mRNA (data not shown). Coexpression of the p38 dominant-negative mutant p38(AGF) had no apparent effect 


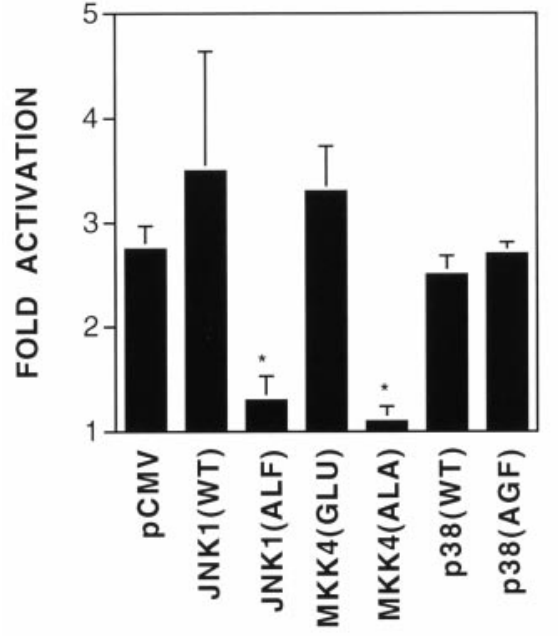

Figure 8. Requirement of JNK in neuregulin-induced AChR $\epsilon$-transgene expression. $\mathrm{C} 2 \mathrm{C} 12$ myoblasts were transiently transfected with $\epsilon 416-\mathrm{Luc}$ and $\mathrm{pCMV} \beta$ with pCMV, pCMV-JNK1(WT), pCMVJNK1(ALF), pCMV-MKK4(Glu), pCMV-MKK4(Ala), pCMVp38(WT), or pCMV-p38(AGF). Twenty-four hours after transfection, myoblasts were incubated with the DM to induce myotube formation. After another $48 \mathrm{hr}$, myotubes were stimulated with $1 \mathrm{~nm}$ neuregulin for $24 \mathrm{hr}$ and then harvested for assays of luciferase and $\beta$-galactosidase activity. The fold of the relative luciferase or $\beta$-galactosidase activity in neuregulin-stimulated cells over that in control cells is shown. Histograms are mean $\pm \mathrm{SD}$ of four different samples. ${ }^{*} p<0.05$.

on the $\epsilon$-transgene transcription activity (Fig. 8). These results suggest that p38 MAP kinase may not contribute to the regulation of AChR gene expression by neuregulin.

Having demonstrated the important role of JNK in the neuregulin-induced $\epsilon$-transgene expression, we next asked whether JNK is also a critical regulator of the expression of the endogenous $\epsilon$-subunit gene in response to neuregulin. To address this issue, the wild type or dominant-negative mutant JNK were introduced into $\mathrm{C} 2 \mathrm{C} 12$ cells by transfection. Both constructs were tagged with a FLAG epitope. Neomycin-resistant clones were screened for expression of JNK proteins by Western blot analysis with anti-FLAG antibodies. We have obtained $\mathrm{C} 2 \mathrm{C} 12$ cell lines that stably expressed the wild type or mutant of JNK1. Figure $9 A$ shows a Western blot demonstrating expression of wild type and mutant JNK1 in two representative cell lines. Similar levels of expression were obtained in other stable cell lines (data not shown). No apparent morphological changes were observed when the JNK wild-type or mutant-expressing $\mathrm{C} 2 \mathrm{C} 12$ cells were compared with the parental cells or the cells transfected with the empty vector. Stable expression of the JNK wild type or mutant did not appear to affect differentiation from myoblasts to myotubes. We examined neuregulin-induced $\epsilon$-mRNA expression in two cell lines that stably expressed wild-type JNK1 and four cell lines that stably expressed mutant JNK1. As shown in Figure 9B, the wild-type JNK1 had no apparent effect on neuregulin's effect; however, the dominant-negative mutant inhibited the neuregulininduced expression of the endogenous $\epsilon$-mRNA. A summary of three independent Northern blot analyses of parental, control (pCMV-transfected), JNK1(WT)\#2, and JNK1(ALF)\#1 cells is presented in Figure $9 C$. These results were in agreement with those with the $\epsilon$-transgene transcription in transient expression experiments, supporting the notion that activation of $\mathrm{JNK}$ is required for neuregulin-induced expression of the $\epsilon$-subunit gene.

\section{DISCUSSION}

Neuregulin-mediated expression of the AChR $\epsilon$-subunit gene in muscle cells requires c-JUN and JNK in addition to the previously documented ERK. First, neuregulin induced expression of immediate early genes $c$-jun and $c$-fos. Expression of $c$-jun and $c$-fos by neuregulin followed and depended on ERK activation, which has been demonstrated to be essential for neuregulinupregulated AChR gene expression. Second, inhibition of protein synthesis or blockade of the c-JUN function by a c-JUN dominant-negative mutant attenuated or abolished neuregulinmediated transcription from the $\epsilon$-promoter. Third, neuregulin activated JNK in muscle cells. Blockade of JNK activation by overexpressing dominant-negative MKK4 inhibited $\epsilon$-promoter activation. Moreover, overexpression of the JNK dominantnegative mutant inhibited neuregulin-mediated expression of the $\epsilon$-transgene and endogenous $\epsilon$-mRNA in muscle cells. These results suggest that neuregulin activates multiple signaling cascades that converge to regulate AChR subunit gene expression.

In contrast to the transient induction of immediate early genes like $c$-fos and $c$-jun, the induction of the $\epsilon$-mRNA was delayed and persisted after neuregulin treatment in $\mathrm{C} 2 \mathrm{C} 12$ myotubes. This time course is similar to that of other delayed-response gene products such as VGF (Levi et al., 1985; Salton et al., 1991), GAP43 (Federoff et al., 1988), transin (Machida et al., 1989), and COS-1 (Kaplan et al., 1997) whose expression is induced by NGF or basic FGF (bFGF) in pheochromocytoma 12 cells. Expression of these messages is also inhibited by cycloheximide. The mechanisms concerning how these delayed-response genes are regulated remain primarily unknown. NGF and bFGF both cause a prolonged activation of Ras resulting in a prolonged increase of ERK activity (Kaplan et al., 1997). The prolonged ERK activation leads to the phosphorylation of the cAMP regulatory element-binding protein for up to several hours that, along with immediate early gene products, leads to subsequent delayedresponse gene expression (Bonni et al., 1995; Segal and Greenberg, 1996). The regulatory mechanisms of the AChR $\epsilon$-subunit gene may be different from those induced by NGF or bFGF because neuregulin activated ERK transiently (Fig. 2).

The c-JUN and c-FOS proteins are the cellular homologs of viral oncogenes. The c-JUN proteins are able to dimerize among themselves or form a heterodimer with c-FOS, whereas c-FOS has to dimerize with c-JUN to form a dimer. These homo- or heterodimers are major components of the activator protein-1 (AP-1) transcription factor (Rauscher et al., 1989; Angel and Karin, 1991; Foletta, 1996). AP-1 plays a role in the regulation of both basal and inducible transcription of various genes in response to growth factors, cytokines, tumor promoters, and carcinogens. c-JUN may directly regulate neuregulin-induced AChR gene expression by binding to the promoter region of the $\epsilon$-subunit gene. That c-JUN affects the neuregulin-induced $\epsilon 416$ Luc transgene expression in $\mathrm{C} 2 \mathrm{C} 12$ myotubes may suggest that the element(s) required for the c-JUN effects, either direct or indirect, lies within the 416 nucleotides in the 5'-flanking region of the $\epsilon$-subunit gene. A careful examination that failed to identify the palindromic sequence 5'TGAg/cTCA, the consensus binding site for AP-1, in this region does not support the notion that c-JUN regulates AChR gene expression by binding to a typical AP-1 element in the 5'-flanking region. An alternative hypothesis is that c-JUN interacts with other transcription factors to regulate $\mathrm{AChR}$ gene expression and thus does not require a direct interaction with a cis-element. 
Figure 9. Attenuation of neuregulin-induced expression of endogenous $\epsilon$-mRNA by dominant-negative JNK1. C2C12 myoblasts were transfected with pCMV, pCMVJNK1(WT), or pCMV-JNK1(ALF). All DNA constructs contained the G418-resistant gene neo. The FLAG epitope was tagged between the codons 1 and 2 of JNK. G418resistant clones were isolated and characterized for JNK1 expression and AChR gene expression in response to $N R G$. $A$, Western blot analysis showing expression of wild-type and mutant JNK1 in the parental and stable cell lines JNK1(WT)\#2 and JNK1(ALF)\#1. Forty micrograms of proteins extracted from the indicated myotubes were resolved on a $10 \%$ SDS-PAGE gel, transferred, and blotted with anti-FLAG antibodies. Similar levels of JNK1 expression were observed in other stable cell lines described in $B . B$, Northern blot analysis. Twenty micrograms of total RNA were used. The loading was uniform as evidenced by an equal amount of GAPDH mRNA. $C$, Histograms showing mean $\pm \mathrm{SD}$ of three different samples. The mRNA level of the parental cell line in the absence of neuregulin was considered to be $100 \% .{ }^{* *} p<0.01$ in comparison with the neuregulin-mediated increase in parental, pCMV, or JNK1(WT)\#2 cells.
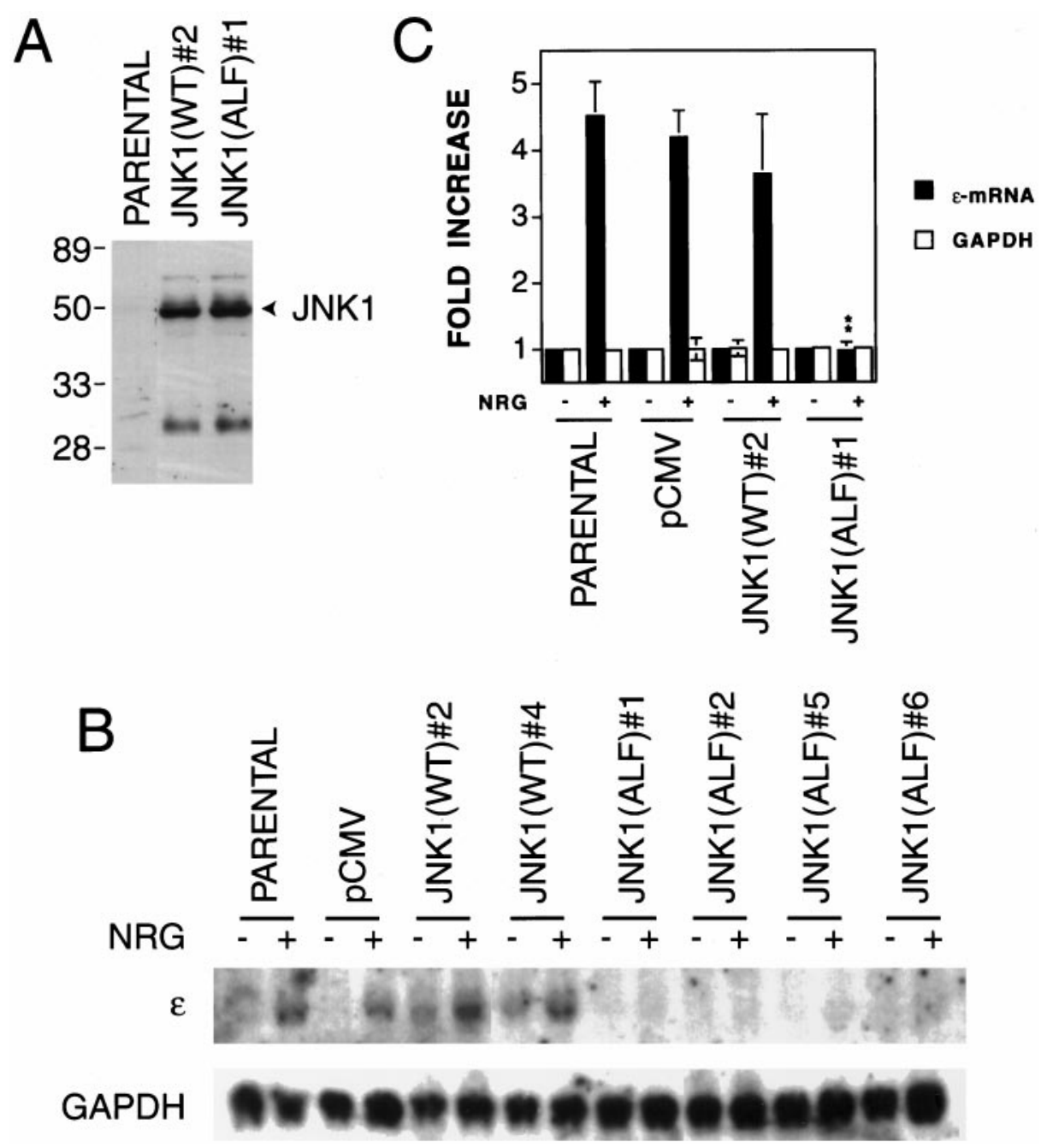

The ETS family of transcription factors may be candidate factors whose function is regulated by c-JUN. Recent studies indicate that ETS2 and GABP, both members of the ETS family, are required for neuregulin-induced and synapse-specific expression of the $\epsilon$-subunit gene (Fromm and Burden, 1998; Sapru et al., 1998; Schaeffer et al., 1998). In a recent report, ETS2 has been found to associate strongly with the c-JUN-c-FOS dimer, and such an interaction is enhanced by promoter DNA containing the ets sites but does not require the AP-1 site (Basuyaux et al., 1997). Thus, c-JUN may regulate the $\epsilon$-promoter transcription via interacting with the ETS family of proteins. It is worth noting that overexpression of the wild-type c-JUN or the MKK4 or JNK active mutant did not increase the basal level of $\epsilon$-promoter transcription, suggesting that c-JUN, MKK4, or JNK is not sufficient to upregulate AChR gene expression. Previous studies have demonstrated that angiotensin II stimulates AP-1-driven transcription and c-JUN-c-FOS heterodimer DNA-binding activity in C2C12 cells (Puri et al., 1995). Treatment of C2C12 myotubes with angiotensin II had no effect on the basal or neuregulin-upregulated expression of the AChR $\epsilon$-subunit (data not shown). These results suggest that c-JUN and/or c-FOS and JNK are required for but not sufficient to mediate the upregulation of AChR gene expression by neuregulin. It is also possible that c-JUN activates transcription of another factor that in turn activates $\epsilon$-subunit gene expression.
Synaptic nuclei continue to express the AChR $\epsilon$-subunit many weeks after the nerve has been removed (Brenner et al., 1990), suggesting an imprint signal capable of inducing AChR expression in the absence of the nerve. This imprint signal is believed to be neuregulin concentrated in the extracellular matrix at the neuromuscular junction. However, denervation decreases dramatically the neuregulin-like immunoreactivity at the neuromuscular junction (Sandrock et al., 1995). Yet the accumulation of AChR mRNA, especially the $\epsilon$-mRNA, is not dependent on the continued presence of the nerve terminal (Goldman and Staple, 1989; Brenner et al., 1990). Our observation of the sustained increase in the AChR mRNA by a brief neuregulin stimulation supports the "imprinting" hypothesis. Clearly, the elevation was not caused by a continuous activation of the ErbB kinases because their activity, monitored by tyrosine phosphorylation, decreased within $15 \mathrm{~min}$ after and returned to the basal level within $60 \mathrm{~min}$ of neuregulin stimulation (Si et al., 1996). Concomitantly, the ERK kinase activation was transient by either continuous or transient stimulation of $\mathrm{C} 2 \mathrm{C} 12$ cells with neuregulin. A simple explanation of this phenomenon is that the AChR mRNA may be stable and, after being synthesized, remains intact in the muscle cells for a longer period of time. Although this possibility cannot be ruled out in the present study; the fact that actinomycin D, an inhibitor of transcription, inhibited the neuregulin-elevated AChR mRNAs suggests a role of continuous active transcription 
in the maintenance of the AChR mRNA. Presumably, the intracellular neuregulin pathway, after being activated, may remain functional without further stimulation from extracellular neuregulin. The prolonged transcription should be mediated by a covalent modulation of transcription regulators in nuclei because the activation of ERK by neuregulin was transient and the phosphorylated MAP kinases were quickly translocated into nuclei in C2C12 myotubes (Si and Mei, unpublished observation). Potential candidate transcription factors are members of the ETS family, whose phosphorylation regulates expression of AChR genes (Sapru et al., 1998; Schaeffer et al., 1998). Alternatively and/or probably in addition, neuregulin may activate novel signaling events to sustain the transcription of AChR genes. The finding that c-JUN and its phosphorylation are required for neuregulin-upregulated expression of the AChR $\epsilon$-subunit gene suggests that the immediate early gene products play an role in maintenance of the AChR $\epsilon$-mRNA in the absence of neuregulin.

\section{REFERENCES}

Altiok N, Bessereau J-L, Changeux J-P (1995) ErbB3 and ErbB2/neu mediate the effect of heregulin on acetylcholine receptor gene expression in muscle: differential expression at the endplate. EMBO $\mathrm{J}$ $14: 4258-4266$.

Altiok N, Altiok S, Changeux JP (1997) Heregulin-stimulated acetylcholine receptor gene expression in muscle: requirement for MAP kinase and evidence for a parallel inhibitory pathway independent of electrical activity. EMBO J 16:717-725.

Angel P, Karin M (1991) The role of Jun, Fos and the AP-1 complex in cell-proliferation and transformation. Biochim Biophys Acta 1072:129-157.

Basuyaux JP, Ferreira E, Stehelin D, Buttice G (1997) The Ets transcription factors interact with each other and with the c-Fos/c-Jun complex via distinct protein domains in a DNA-dependent and -independent manner. J Biol Chem 272:26188-26195.

Bengal E, Ransone L, Scharfmann R, Dwarki VJ, Tapscott SJ, Weintraub H, Verma I (1992) Functional antagonism between c-Jun and MyoD proteins: a direct physical association. Cell 68:507-519.

Bonni A, Ginty DD, Dudek H, Greenberg ME (1995) Serine 133phosphorylated CREB induces transcription via a cooperative mechanism that may confer specificity to neurotrophin signals. Mol Cell Neurosci 6:168-183.

Bradford MM (1976) A rapid and sensitive method for the quantitation of microgram quantities of protein utilizing the principle of protein-dye binding. Anal Biochem 72:248-254.

Brenner HR, Witzemann V, Sakmann B (1990) Imprinting of acetylcholine receptor messenger RNA accumulation in mammalian neuromuscular synapses. Nature 344:544-547.

Brown PH, Chen TK, Birrer MJ (1994) Mechanism of action of a dominant-negative mutant of c-Jun. Oncogene 9:791-799.

Brown PH, Kim SH, Wise SC, Sabichi AL, Birrer MJ (1996) Dominantnegative mutants of cJun inhibit AP-1 activity through multiple mechanisms and with different potencies. Cell Growth Differ 7:1013-1021.

Carraway KL, Soltoff SP, Diamonti AJ, Cantley LC (1995) Heregulin stimulates mitogenesis and phosphatidylinositol 3-kinase in mouse fibroblasts transfected with erbB2/neu and erbB3. J Biol Chem 270:7111-7116.

Chomczynski P, Sacchi N (1987) Single-step method of RNA isolation by acid guanidinium thiocyanate-phenol-chloroform extraction. Anal Biochem 162:156-159.

Chu GC, Moscoso LM, Sliwkowski MX, Merlie JP (1995) Regulation of the acetylcholine receptor e subunit gene by recombinant ARIA: an in vitro model for transynaptic gene regulation. Neuron 14:329-339.

Chung J, Kuo CJ, Crabtree GR, Blenis J (1992) Rapamycin-FKBP specifically blocks growth-dependent activation of and signaling by the 70 kd S6 protein kinase. Cell 69:1227-1237.

Corfas G, Falls DL, Fischbach GD (1993) ARIA, a protein that stimulates acetylcholine receptor synthesis, also induces tyrosine phosphorylation of a $185-\mathrm{kDa}$ muscle transmembrane protein. Proc Natl Acad Sci USA 90:1624-1628.

Curran T, Gordon MB, Rubino KL, Sambucetti LC (1987) Isolation and characterization of the c-fos(rat) cDNA and analysis of posttranslational modification in vitro. Oncogene 2:79-84.

Duclert A, Savatier N, Changeux JP (1993) An 83-nucleotide promoter of the acetylcholine receptor epsilon-subunit gene confers preferential synaptic expression in mouse muscle. Proc Natl Acad Sci USA 90:3043-3047.

Duclert A, Savatier N, Schaeffer L, Changeux J-P (1996) Identification of an element crucial for the sub-synaptic expression of the acetylcholine receptor epsilon-subunit gene. J Biol Chem 271:17433-17438.

Dudley DT, Pang L, Decker SJ, Bridges AJ, Saltiel AR (1995) A synthetic inhibitor of the mitogen-activated protein kinase cascade. Proc Natl Acad Sci USA 92:7686-7689.

Falls DL, Rosen KM, Corfas G, Lane WS, Fischbach GD (1993) ARIA, a protein that stimulates acetylcholine receptor synthesis, is a member of the Neu ligand family. Cell 72:801-815.

Federoff HJ, Grabczyk E, Fishman MC (1988) Dual regulation of GAP-43 gene expression by nerve growth factor and glucocorticoids. J Biol Chem 263:19290-19295.

Fischbach GD, Cohen SA (1973) The distribution of acetylcholine sensitivity over uninnervated and innervated muscle fibers grown in cell culture. Dev Biol 31:147-162.

Fischbach GD, Rosen KM (1997) ARIA: a neuromuscular junction neuregulin. Annu Rev Neurosci 20:429-458.

Foletta VC (1996) Transcription factor AP-1, and the role of Fra-2. Immunol Cell Biol 74:121-133.

Froehner SC (1993) Regulation of ion channel distribution at synapses. Annu Rev Neurosci 16:347-368.

Fromm L, Burden SJ (1998) Synapse-specific and neuregulin-induced transcription require an Ets site that binds $\mathrm{GABPa} / \mathrm{GABPb}$. Genes Dev 12:3074-3083.

Goldman D, Staple J (1989) Spatial and temporal expression of acetylcholine receptor RNAs in innervated and denervated rat soleus muscle. Neuron 3:219-228.

Goodearl ADJ, Yee AG, Sandrock Jr AW, Corfas G, Fischbach GD (1995) ARIA is concentrated in the synaptic basal lamina of the developing chick neuromuscular junction. J Cell Biol 130:1423-1434.

Greenberg ME, Ziff EB (1984) Stimulation of 3 T3 cells induces transcription of the c-fos proto-oncogene. Nature 311:433-438.

Greenberg ME, Hermanowski AL, Ziff EB (1986) Effect of protein synthesis inhibitors on growth factor activation of c-fos, c-myc, and actin gene transcription. Mol Cell Biol 6:1050-1057.

Gundersen K, Sanes JR, Merlie JP (1993) Neural regulation of muscle acetylcholine receptor epsilon- and alpha-subunit gene promoters in transgenic mice. J Cell Biol 123:1535-1544.

Gupta S, Campbell D, Derijard B, Davis RJ (1995) Transcription factor ATF2 regulation by the JNK signal transduction pathway. Science 267:389-393.

Hall ZW, Sanes JR (1993) Synaptic structure and development: the neuromuscular junction. Cell [Suppl] 72:99-121.

Han J, Lee JD, Bibbs L, Ulevitch RJ (1994) A MAP kinase targeted by endotoxin and hyperosmolarity in mammalian cells. Science 265:808-811.

Holmes WE, Sliwkowski MX, Akita RW, Kenzel WJ, Lee J, Park JW, Yansura D, Abadi N, Raab H, Lewis GD, Shepard HM, Huang WJ, Wood WJ, Goeddel DV, Vandlen RL (1992) Identification of heregulin, a specific activator of p185erbB2. Science 256:1205-1210.

Jessell TM, Siegel RE, Fischbach GD (1979) Induction of acetylcholine receptors on cultured skeletal muscle by a factor extracted from brain and spinal cord. Proc Natl Acad Sci USA 76:5397-5401.

Jo SA, Zhu X, Marchionni MA, Burden SJ (1995) Neuregulins are concentrated at nerve-muscle synapses and activate ACh-receptor gene expression. Nature 373:158-161.

Kaplan MD, Olschowka JA, O'Banion MK (1997) Cyclooxygenase-1 behaves as a delayed response gene in PC12 cells differentiated by nerve growth factor. J Biol Chem 272:18534-18537.

Klarsfeld A, Daubas P, Bourachot B, Changeux JP (1987) A 5' flanking region of the chicken acetylcholine receptor alpha-subunit gene confers tissue-specificity and developmental control of expression in transfected cells. Mol Cell Biol 7:951-955.

Lee JC, Laydon JT, McDonnell PC, Gallagher TF, Kumar S, Green D, McNulty D, Blumenthal MJ, Heys JR, Landvatter SW, Strickler JE, McLaughlin MM, Siemens IR, Fisher SM, Livi GR, White JR, Adams JL, Young PR (1994) A protein kinase involved in the regulation of inflammatory cytokine biosynthesis. Nature 372:739-746.

Lehrach H, Diamond D, Worney JM, Boedtker H (1977) RNA molec- 
ular weight determinations by gel electrophoresis under denaturing conditions. Biochemistry 16:4743-4751.

Levi A, Eldridge JD, Paterson BM (1985) Molecular cloning of a gene sequence regulated by nerve growth factor. Science 229:393-395.

Levitzki A, Gazit A (1995) Tyrosine kinase inhibition: an approach to drug development. Science 267:1782-1788.

Li L, Chambard JC, Karin M, Olson EN (1992) Fos and Jun repress transcriptional activation by myogenin and MyoD: the amino terminus of Jun can mediate repression. Genes Dev 6:676-689.

Loeb JA, Fischbach GD (1995) ARIA can be released from extracellular matrix through cleavage of a heparin-binding domain. J Cell Biol 130:127-135.

Machida CM, Rodland KD, Matrisian L, Magun BE, Ciment G (1989) NGF induction of the gene encoding the protease transin accompanies neuronal differentiation in PC12 cells. Neuron 2:1587-1596.

Marchionni MA, Goodearl ADJ, Chen MS, Bermingham-McDonogh O, Kirk C, Hendricks M, Danehy F, Misumi D, Sudhalter J, Kobayashi K, Wroblewski D, Lynch C, Baldassare M, Hiles I, Davis JB, Hsuan JJ, Totty NF, Otsu M, McBurney RN, Waterfield MD, Stroobant P, Gwynne D (1993) Glial growth factors are alternatively spliced erbB2 ligands expressed in the nervous system. Nature 362:312-318.

Martinou JC, Falls DL, Fischbach GD, Merlie JP (1991) Acetylcholine receptor-inducing activity stimulates expression of the epsilon-subunit gene of the muscle acetylcholine receptor. Proc Natl Acad Sci USA 88:7669-7673.

Natali PG, Nicotra MR, Sures I, Mottolese M, Botti C, Ullrich A (1992) Breast cancer is associated with loss of the c-kit oncogene product. Int J Cancer 52:713-717.

Puri PL, Avantaggiati ML, Burgio VL, Chirillo P, Collepardo D, Natoli G, Balsano C, Levrero M (1995) Reactive oxygen intermediates mediate angiotensin II-induced c-Jun'c-Fos heterodimer DNA binding activity and proliferative hypertrophic responses in myogenic cells. J Biol Chem 270:22129-22134.

Raingeaud J, Gupta S, Rogers JS, Dickens M, Han J, Ulevitch RJ, Davis RJ (1995) Pro-inflammatory cytokines and environmental stress cause p38 mitogen-activated protein kinase activation by dual phosphorylation on tyrosine and threonine. J Biol Chem 270:7420-7426.

Rauscher III FJ, Voulalas PJ, Franza Jr BR, Curran T (1988) Fos and Jun bind cooperatively to the AP-1 site: reconstitution in vitro. Genes Dev 2:1687-1699.

Salton SR, Fischberg DJ, Dong KW (1991) Structure of the gene encoding VGF, a nervous system-specific mRNA that is rapidly and selectively induced by nerve growth factor in PC12 cells. Mol Cell Biol 11:2335-2349.

Sambrook J, Fritsch EF, Maniatis T (1989) Molecular cloning: a laboratory manual. Cold Spring Harbor, NY: Cold Spring Harbor Laboratory.

Sanchez I, Hughes RT, Mayer BJ, Yee K, Woodgett JR, Avruch J, Kyriakis JM, Zon LI (1994) Role of SAPK/ERK kinase-1 in the stress-activated pathway regulating transcription factor c-Jun. Nature 372:794-798.

Sandrock AW, Dryer SE, Rosen KM, Gozani SN, Kramer R, Theill LE, Fischbach GD (1997) Maintenance of acetylcholine receptor number by neuregulins at the neuromuscular junction in vivo. Science 276:599-603.
Sandrock Jr AW, Goodearl AD, Yin QW, Chang D, Fischbach GD (1995) ARIA is concentrated in nerve terminals at neuromuscular junctions and at other synapses. J Neurosci 15:6124-6136.

Sanes JR, Lichtman JW (1999) Development of the vertebrate neuromuscular junction. Annu Rev Neurosci 22:389-442.

Sanes JR, Johnson YR, Kotzbauer PT, Mudd J, Hanley T, Martinou JC, Merlie JP (1991) Selective expression of an acetylcholine receptorlacZ transgene in synaptic nuclei of adult muscle fibers. Development 113:1181-1191.

Sapru MK, Florance SK, Kirk C, Goldman D (1998) Identification of a neuregulin and protein-tyrosine phosphatase response element in the nicotinic acetylcholine receptor e subunit gene: regulatory role of an ets transcription factor. Proc Natl Acad Sci USA 95:1289-1294.

Schaeffer L, Duclert N, Huchet-Dymanus M, Changeux J-P (1998) Implication of a multisubunit Ets-related transcription factor in synaptic expression of the nicotinic acetylcholine receptor. EMBO J 17:3078-3090.

Segal RA, Greenberg ME (1996) Intracellular signaling pathways activated by neurotrophic factors. Annu Rev Neurosci 19:463-489.

Si J, Mei L (1999) ERK MAP kinase activation is required for ARIAinduced increase in all five AChR subunit mRNAs as well as synapsespecific expression of the AChR epsilon-transgene. Mol Brain Res 67:18-27.

Si J, Luo Z, Mei L (1996) Induction of acetylcholine receptor gene expression by ARIA requires activation of mitogen-activated protein kinase. J Biol Chem 271:19752-19759.

Si J, Miller DS, Mei L (1997) Identification of an element required for acetylcholine receptor-inducing activity (ARIA)-induced expression of the acetylcholine receptor epsilon subunit gene. J Biol Chem 272:10367-10371.

Simon AM, Hoppe P, Burden SJ (1992) Spatial restriction of AChR gene expression to subsynaptic nuclei. Development 114:545-553.

Tang J, Jo SA, Burden SJ (1994) Separate pathways for synapse-specific and electrical activity-dependent gene expression in skeletal muscle. Development 120:1799-1804.

Tansey MG, Chu GC, Merlie JP (1996) ARIA/HRG regulates AChR epsilon subunit gene expression at the neuromuscular synapse via activation of phosphatidylinositol 3-kinase and Ras/MAPK pathway. J Cell Biol 134:465-476.

Usdin TB, Fischbach GD (1986) Purification and characterization of a polypeptide from chick brain that promotes the accumulation of acetylcholine receptors in chick myotubes. J Cell Biol 103:493-507.

Wen D, Peles E, Cupples R, Suggs SV, Bacus SS, Luo Y, Trail G, Hu S, Silbiger SM, Levy RB, Koski RA, Lu HS, Yarden Y (1992) Neu differentiation factor: a transmembrane glycoprotein containing an EGF domain and an immunoglobulin homology unit. Cell 69:559-572.

Whitmarsh AJ, Shore P, Sharrocks AD, Davis RJ (1995) Integration of MAP kinase signal transduction pathways at the serum response element. Science 269:403-407.

Whitmarsh AJ, Yang SH, Su MSS, Sharrocks AD, Davis RJ (1997) Role of p38 and JNK mitogen-activated protein kinases in the activation of ternary complex factors. Mol Cell Biol 17:2360-2371.

Zhu X, Lai C, Thomas S, Burden SJ (1995) Neuregulin receptors, erbB3 and erbB4, are localized at neuromuscular synapses. EMBO J 23:58425848 . 